\title{
Effect of Raphanus sativus (Radish) Leaf Extract and High Doses of Atorvastatin on Body Weight, Liver Weight and Liver/Body Weight Ratio
}

\author{
Obaid Anwar', Mazhar Iqbal'2, Asad Mahmood Khan ${ }^{3}$, Shahzad Tariq ${ }^{4}$, Aisha Ambreen ${ }^{5}$
}

1 Assistant Professor, Department of Pharmacology, Faisalabad Medical University, Faisalabad Pakistan

Data collection, Data analysis

2 Research Officer, PHRC, Research Centre, Faisalabad Medical University, Faisalabad Pakistan

2 Drafting the article, References collection, Data analysis

3 Associate Professor, Department of Pharmacology, Faisalabad Medical University, Faisalabad Pakistan Approved final draft, Data collection

4 Lecturer, Department of Microbiology, Khairpur Medical College, Khairpur Pakistan

4 Helped in discussion writing

5 Senior Demonstrator, Department of Biochemistry, Faisalabad Medical University, Faisalabad Pakistan Approved Final Draft, Data collection

\author{
Submitted for Publication: 15-10-2019 \\ Accepted for Publication 14-10-2020 \\ CORRESPONDING AUTHOR \\ Mazhar Iqbal \\ Research Officer, PHRC, Research Centre \\ Faisalabad Medical University, Faisalabad Pakistan \\ Email: mazhar.iqbal174@gmail.com
}

\section{ABSTRACT}

Background: Obesity is a global health problem. The chances of metabolic disorders such as type 2 diabetes, systemic hypertension, cardiovascular disease, dyslipidemia, and atherosclerosis are increased due to obesity. Objective: (1) To determine effects of high doses of atorvastatin on body weight, liver weight and liver/body weight ratio in albino rabbits. (2) To compare the effect of three increasing doses of ethanolic extract of Raphanus sativus leaf with high doses of atorvastatin on body weight, liver weight and liver/body weight ratio in albino rabbits. Study Design: Experimental study. Settings: Department of Physiology and Pharmacology, University of Agriculture, Faisalabad Pakistan. Duration: 1 year. Methodology: The ethanolic extract of Raphanus sativus was screened for additional beneficial effects on body weight and liver weight by atorvastatin. Results: The results were compared with normal and experimental control by measuring body weight and liver weight after 28 days. There was a very highly significant reduction in weight in all groups when compared with the negative control group A. when compared to the positive control group B no significant change was observed in group C, D and E. The liver weight decreased when Raphanus sativus was added to atorvastatin and a significant effect was seen in in group E. Conclusion: Atorvastatin in high doses decreased the body weight but the combined use of Raphanus sativus and atorvastatin had no significant effect regarding liver weight addition of Raphanus sativus showed a decrease in weight of liver while an increase was seen with atorvastatin alone.

Keywords: Raphanus sativus, Leaf Extract, Atorvastatin.

How to Cite: Anwar O, Iqbal M, Khan AM, Tariq S, Ambreen A. Effect of Raphanus sativus (Radish) Leaf Extract and High Doses of Atorvastatin on Body Weight, Liver Weight and Liver/Body Weight Ratio. APMC 2020;14(4):313-7. DOI: 10.29054/ APMC/2020.721

\section{INTRODUCTION}

Automation has not only changes to the standard of living but also affected the health of the people. Diet rich of saturated fats and refined sugar with low fiber are the result of society's modernization. Statistics are showing a continuing shift towards "Western Diets". ${ }^{1,2}$

Obesity is an emerging problem which results not only in significant comorbid conditions but also in death of people because of the disease which are related to weight in addition to abridged life quality. Obesity and accumulation of fats around visceral organs of body prompts the complications such as atherosclerosis, hepatic steatosis, and type 2 diabetes. It is evident from rising incidence of obesity that this epidemic will be worsened in coming days. ${ }^{3}$

The animal models server as useful tool to assess the ability of potential compounds for prevention and management of obesity. As reported in literature the rodents fed on high-fat diet are an excellent model of obesity whereas the dietetic environment is a key contributor. Moreover, prolonged exposure to a diet rich with fat stimulates adipogenesis and the metabolic syndrome in animal models and can moderate the inflammatory responses. ${ }^{4}$

The plants which contain ingredients or their precursors used for the synthesis of useful drugs for therapeutic purposes are called medicinal plants. All the cultures are using medicinal plants as a source of medicine since ancient times. More than 5000 plants are identified to be used for therapeutic purposes. The olden man has used the plants as their key source for fighting numerous illnesses and therefore protecting his health. Presently, numerous agricultural plants are custom in folk-medicine for cure of several ailments. ${ }^{5,6}$

Radish is grownup and utilized all over the world not only eaten as raw crunchy salad but also has numerous remedial actions. Traditionally its leaves, seeds and roots have been in use for several disorders such 
gastrointestinal, cardiac, biliary, hepatic, urological and respiratory. Raphanus sativus is rich in bioactive compounds and used to prevent weight gain by improving antioxidant status and increased lipid metabolism. ${ }^{3}$

Atorvastatin in a dose of $0.6 \mathrm{mg} / \mathrm{kg}$ by weight for six weeks lead to an increase in body weight. ${ }^{7}$ A study by Salem and his colleagues showed a 30\% reduction in body weight when simvastatin $(10 \mathrm{mk} / \mathrm{kg})$ was administered for ten weeks in rats. ${ }^{8}$ On the other hand another study conducted in patients who were taking statins for one year showed an increase in body weight. ${ }^{9}$

Purpose of Study/Objectives: (1) To determine effects of high doses of atorvastatin on body weight, liver weight and liver/body weight ratio in albino rabbits. (2) To compare the effect of three increasing doses of ethanolic extract of Raphanus sativus leaf with high doses of atorvastatin on body weight, liver weight and liver/body weight ratio in albino rabbits.

\section{METHODOLOGY}

Study Design: Experimental study.

Settings: Department of Pharmacology and Therapeutics, Post Graduate Medical Institute, Lahore and Department of Physiology and Pharmacology, University of Agriculture, Faisalabad. Pakistan.

Duration: 1 year.

Sample Size: 50 Adult Male Rabbits

Data Collection Procedure: Ethical approval of the study was taken from Ethical Review Committee (ERC), University of Health Sciences, Lahore Pakistan.

Plant Material: $100 \mathrm{~kg}$ fresh leaves of Raphanus sativus were purchased from the local vegetable market of Faisalabad, Pakistan. Taxonomic identification of the material was carried out in University of Agriculture, Faisalabad, Pakistan with the available keys (Herbarium voucher no. 173-14-1). Fresh leaves were splashed thoroughly to remove dirt or any excessive material. The leaves were dried at room temperature for 10 days. They were further dried in a hot air oven at $60^{\circ} \mathrm{C}$ for six hours and then grinded in an electric grinder. The powder obtained was passed through mesh sieve and then extracted with $80 \%$ ethanol and filtered with filter paper (Whatman No. 2). The extracts were concentrated in a hot air oven at $37^{\circ} \mathrm{C}$, lyophilized by freeze drying apparatus (Christ Germany model \# Alpha 1- 4LSC) and subsequently air tightly stored at $-20^{\circ} \mathrm{C}(10)$.

Chemicals Atorvastatin of $99 \%$ purity was obtained from Stand Pharm Pharmaceuticals (PVT) Ltd. Lahore Pakistan. 2gms of it was dissolved in $100 \mathrm{ml}$ of distilled water yielding $20 \mathrm{mg}$ atorvastatin in $1 \mathrm{ml}$-distilled water for administration.

Animals: 50 adult male rabbits of 6-8 weeks old, weighing 1 to $1.5 \mathrm{~kg}$ were acquired from the market of Faisalabad, Pakistan. The animals were housed in individual labeled iron cages of appropriate size in the department of Clinical Medicine and Surgery, University of Agriculture, Faisalabad, Pakistan at room temperature with appropriate aeration during the experiment. Rabbits were nourished on seasonal food and grain with water ad libitum. Prior to experimentation, the rabbits were acclimatized for one week. All rabbits were kept starved for 16-18 hours before the administration of test extracts.

Study Design
Group No. of
rabbits
Treatment

$\begin{array}{ccc}\begin{array}{c}\text { A (Normal } \\ \text { control) }\end{array} & 10 & \begin{array}{c}\text { Routine diet throughout the } \\ \text { experiment for } 28 \text { days. }\end{array}\end{array}$

B (Positive
control) 10

Treated daily with atorvastatin (20mg/kg b.w.) as hepatotoxic drug P.O. for 28 days.

Treated daily with atorvastatin (20mg/kg b.w.) + R. sativus leaf extract $(100 \mathrm{mg} / \mathrm{kg}$ b.w.) P.O. for 28 days.

Treated daily with atorvastatin (20mg/kg b.w.) + R. sativus leaf extract $(200 \mathrm{mg} / \mathrm{kg}$ b.w.) P.O. for 28 days.

Treated daily with atorvastatin

$\mathrm{E}$
$\underset{\text { (Experimental }}{\text { group III) }}$
leaf extract $(400 \mathrm{mg} / \mathrm{kg}$ b.w.) P.O. for 28 days.

Study Parameters: Body weight was measured every week and liver was weighed on $28^{\text {th }}$ day after sacrificing rabbits.

Statistical Analysis: Data was analyzed using Statistical Package for Social Sciences version 20.0. Mean \pm SE was calculated. ANOVA was used to note group mean differences. Post Hoc Tukey's test was applied to observe group differences. P-value $\leq 0.05$ was considered as statistically significant.

\section{RESULTS}

Bodyweight: A decrease in body weight was observed in all treated groups while the normal showed an increase in weight. The maximum decrease was observed in group E. When compared by one-way analysis of variance, it was observed that all groups were similar on day 0 and 7 but significantly different on day 14, 21 and 28 . 
Table 1: Effect of R. sativus extract on body weight (Kg) of atorvastatin treated rabbits. Data indicates mean + SE $(\mathrm{n}=10)$

\begin{tabular}{|c|c|c|c|c|c|}
\hline Groups & 0 Day & $\begin{array}{l}7^{\text {th }} \\
\text { Day }\end{array}$ & $\begin{array}{l}14^{\text {th }} \\
\text { Day }\end{array}$ & $\begin{array}{l}21^{\text {st }} \\
\text { Day }\end{array}$ & $\begin{array}{l}28^{\text {th }} \\
\text { Day }\end{array}$ \\
\hline A (normal) & $\begin{array}{l}1.53 \pm \\
0.038\end{array}$ & $\begin{array}{l}1.54 \pm \\
0.036 \\
\end{array}$ & $\begin{array}{c}1.53 \pm \\
0.024 \\
\end{array}$ & $\begin{array}{l}1.57 \pm \\
0.037\end{array}$ & $\begin{array}{l}1.58 \pm \\
0.036 \\
\end{array}$ \\
\hline B (At. $20 \mathrm{mg} / \mathrm{kg})$ & $\begin{array}{l}1.59 \pm \\
0.036\end{array}$ & $\begin{array}{l}1.50 \pm \\
0.035\end{array}$ & $\begin{array}{l}1.41 \pm \\
0.036\end{array}$ & $\begin{array}{l}1.35 \pm \\
0.038\end{array}$ & $\begin{array}{l}1.28 \pm \\
0.045 \\
\end{array}$ \\
\hline $\begin{array}{c}\mathrm{C}(\text { At } 20 \mathrm{mg} / \mathrm{kg}+R S \\
100 \mathrm{mg} / \mathrm{kg})\end{array}$ & $\begin{array}{l}1.54 \pm \\
0.029\end{array}$ & $\begin{array}{l}1.48 \pm \\
0.028\end{array}$ & $\begin{array}{c}1.42 \pm \\
0.038 \\
\end{array}$ & $\begin{array}{l}1.37 \pm \\
0.041\end{array}$ & $\begin{array}{l}1.30 \pm \\
0.041\end{array}$ \\
\hline $\begin{array}{c}\mathrm{D}(\text { At } 20 \mathrm{mg} / \mathrm{kg}+R S \\
200 \mathrm{mg} / \mathrm{kg})\end{array}$ & \begin{tabular}{|l|}
$1.58 \pm$ \\
0.025 \\
\end{tabular} & $\begin{array}{l}1.53 \pm \\
0.037\end{array}$ & $\begin{array}{l}1.48 \pm \\
0.030 \\
\end{array}$ & $\begin{array}{l}1.41 \pm \\
0.036 \\
\end{array}$ & $\begin{array}{l}1.35 \pm \\
0.032 \\
\end{array}$ \\
\hline $\begin{array}{c}\text { E (At } 20 \mathrm{mg} / \mathrm{kg}+R S \\
400 \mathrm{mg} / \mathrm{kg})\end{array}$ & $\begin{array}{c}1.59 \pm \\
0.040 \\
\end{array}$ & $\begin{array}{l}1.50 \pm \\
0.041\end{array}$ & $\begin{array}{c}1.40 \pm \\
0.035\end{array}$ & $\begin{array}{l}1.32 \pm \\
0.043\end{array}$ & $\begin{array}{l}1.25 \pm \\
0.041\end{array}$ \\
\hline ANOVA (P-value) & $\begin{array}{c}0.616 \\
\text { NS }\end{array}$ & $\begin{array}{c}0.769 \\
\text { NS }\end{array}$ & $0.035^{*}$ & $\begin{array}{c}0.000^{* *} \\
*\end{array}$ & $\begin{array}{c}0.000^{* *} \\
*\end{array}$ \\
\hline
\end{tabular}

NS = Not-significant $(\mathrm{P} \geq 0.05) ;{ }^{*}=$ Significant $(\mathrm{P} \leq 0.05) ;{ }^{*}=$ Highly significant $(\mathrm{P} \leq 0.01) ;{ }^{* * *}=$ Very highly significant $(\mathrm{P} \leq 0.001$

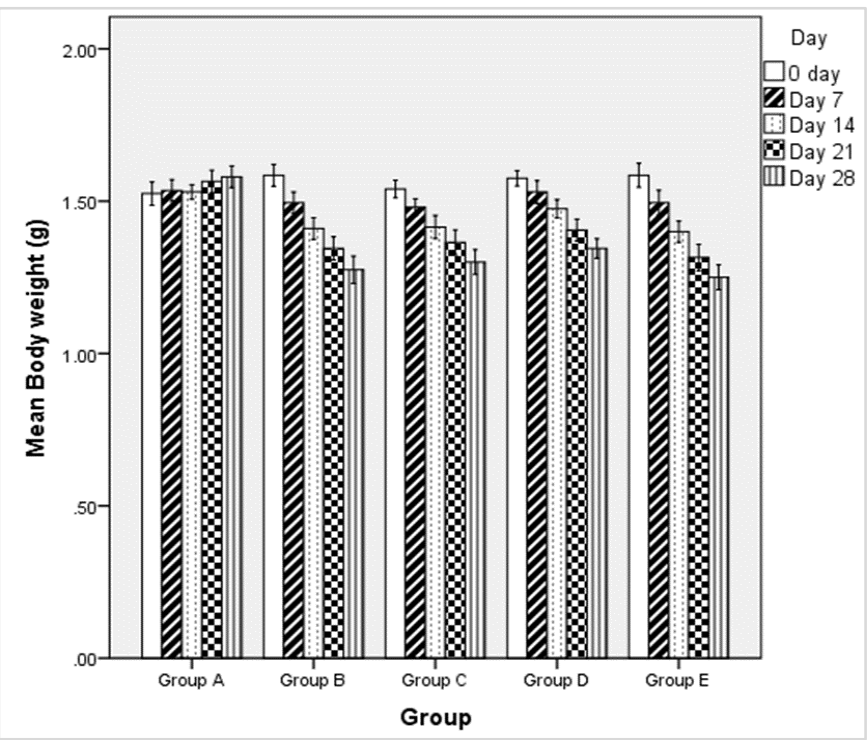

Figure 1: Effect of $R$. sativus extract on bodyweight $($ mean $+S E)$ of atorvastatin treated rabbits $(n=10)$

Group A: Normal; Group B: Atorvastatin $20 \mathrm{mg} / \mathrm{kg}$ b.w./day; Group C: Atorvastatin 20mg/kg b. w./day + R. sativus E. extract $100 \mathrm{mg} / \mathrm{kg}$ b.w./day; Group D: Atorvastatin $20 \mathrm{mg} / \mathrm{kg} \mathrm{b}$. w./ day plus R. sativus E. extract $200 \mathrm{mg} / \mathrm{kg}$ b.w./day; Group E: Atorvastatin $20 \mathrm{mg} / \mathrm{kg}$ b. w./day plus R. sativus E. extract $400 \mathrm{mg} / \mathrm{kg}$ b.w./day.

Multiple comparison of body weight by post Hoc Tukey's test showed a very highly significant reduction in weight in all the treated groups on $28^{\text {th }}$ day when compared with the negative control group A. When compared with the +ve control, the decline was insignificant in all groups. Difference between treated groups was also not significant.
Table 2: Comparison of means of body weight among various groups by post Hoc Tukey's test

\begin{tabular}{|c|c|c|c|c|c|c|}
\hline \multirow{2}{*}{\multicolumn{2}{|c|}{ Groups }} & \multicolumn{5}{|c|}{ Significance } \\
\hline & & Day 0 & Day 7 & Day 14 & Day 21 & Day 28 \\
\hline \multirow{4}{*}{ Group A } & $\mathrm{B}$ & $0.721^{\mathrm{NS}}$ & $0.434^{\mathrm{NS}}$ & $0.025^{*}$ & $0.000^{\text {*** }}$ & $0.000^{* * *}$ \\
\hline & $\mathrm{C}$ & $0.998^{\mathrm{NS}}$ & $0.283^{\mathrm{NS}}$ & $0.032^{*}$ & $0.001^{* *}$ & $0.000^{* * *}$ \\
\hline & $\mathrm{D}$ & $0.834^{\mathrm{NS}}$ & $0.922^{\mathrm{NS}}$ & $0.295^{\mathrm{NS}}$ & $0.006^{* *}$ & $0.000^{* * *}$ \\
\hline & E & $0.721^{\mathrm{NS}}$ & $0.434^{\mathrm{NS}}$ & $0.016^{*}$ & $0.000^{* * *}$ & $0.000^{* * *}$ \\
\hline \multirow{3}{*}{ Group B } & $\mathrm{C}$ & $0.880^{\mathrm{NS}}$ & $0.768^{\mathrm{NS}}$ & $0.924^{\mathrm{NS}}$ & $0.720^{\mathrm{NS}}$ & $0.654^{\mathrm{NS}}$ \\
\hline & $\mathrm{D}$ & $1.000^{\mathrm{NS}}$ & $0.493^{\mathrm{NS}}$ & $0.217^{\mathrm{NS}}$ & $0.284^{\mathrm{NS}}$ & $0.213^{N S}$ \\
\hline & $E$ & $1.000^{\mathrm{NS}}$ & $1.000^{\mathrm{NS}}$ & $0.848^{\mathrm{NS}}$ & $0.591^{\mathrm{NS}}$ & $0.654^{\mathrm{NS}}$ \\
\hline \multirow{2}{*}{ Group C } & $\mathrm{D}$ & $0.948^{\mathrm{NS}}$ & $0.329^{\mathrm{NS}}$ & $0.254^{\mathrm{NS}}$ & $0.474^{\mathrm{NS}}$ & $0.421^{\mathrm{NS}}$ \\
\hline & $E$ & $0.880^{\mathrm{NS}}$ & $0.768^{\mathrm{NS}}$ & $0.774^{\mathrm{NS}}$ & $0.371^{\mathrm{NS}}$ & $0.371^{\mathrm{NS}}$ \\
\hline Group D & E & $1.000^{\mathrm{NS}}$ & $0.493^{\mathrm{NS}}$ & $0.156^{\mathrm{NS}}$ & $0.111^{\mathrm{NS}}$ & $0.093^{\mathrm{NS}}$ \\
\hline
\end{tabular}

NS = Non-significant $(\mathrm{P}>0.05) ;{ }^{*}=$ Significant $(\mathrm{P} \leq 0.05) ;{ }^{* *}=$ Highly significant $(\mathrm{P} \leq 0.01) ;{ }^{* * *}=$ Very highly significant $(\mathrm{P} \leq 0.001)$

Liver weight: Mean \pm SE values of liver weight in all groups on $28^{\text {th }}$ day showed highest in group $B$ and lowest in group E. When compared by one-way analysis of variance, it was observed that all groups were significantly different.

Table 3: Effect of $\mathbf{R}$. sativus extract on liver weight (g) of atorvastatin treated rabbits. Data indicates mean + SE $(\mathrm{n}=10)$

\begin{tabular}{|l|c|}
\hline Group & Mean \pm SE \\
\hline A: $($ control) & $41.04 \pm 0.59$ \\
\hline B: $($ At $20 \mathrm{mg} / \mathrm{kg} /$ day) & $45.75 \pm 0.34$ \\
\hline $\begin{array}{l}\text { C: }(\text { At } 20 \mathrm{mg} / \mathrm{kg} / \text { day + R. S } \\
100 \mathrm{mg} / \mathrm{kg} / \text { day) }\end{array}$ & $40.30 \pm 0.90$ \\
\hline $\begin{array}{l}\text { D: }(\text { At } 20 \mathrm{mg} / \mathrm{kg} / \text { day + R. S } \\
200 \mathrm{mg} / \mathrm{kg} / \text { day) }\end{array}$ & $41.27 \pm 1.07$ \\
\hline $\begin{array}{l}\text { E: }(\text { At } 20 \mathrm{mg} / \mathrm{kg} / \text { day + R. S } \\
400 \mathrm{mg} / \mathrm{kg} / \text { day) }\end{array}$ & $37.54 \pm 2.46$ \\
\hline ANOVA (P-Value) & $0.002^{* *}$ \\
\hline
\end{tabular}

NS = Non-significant $(\mathrm{P} \geq 0.05) ;{ }^{*}=$ Significant $(\mathrm{P} \leq 0.05) ;{ }^{*}$ = Highly significant $(\mathrm{P} \leq 0.01) ;{ }^{* * *}=$ Very highly significant $(\mathrm{P} \leq 0.001)$

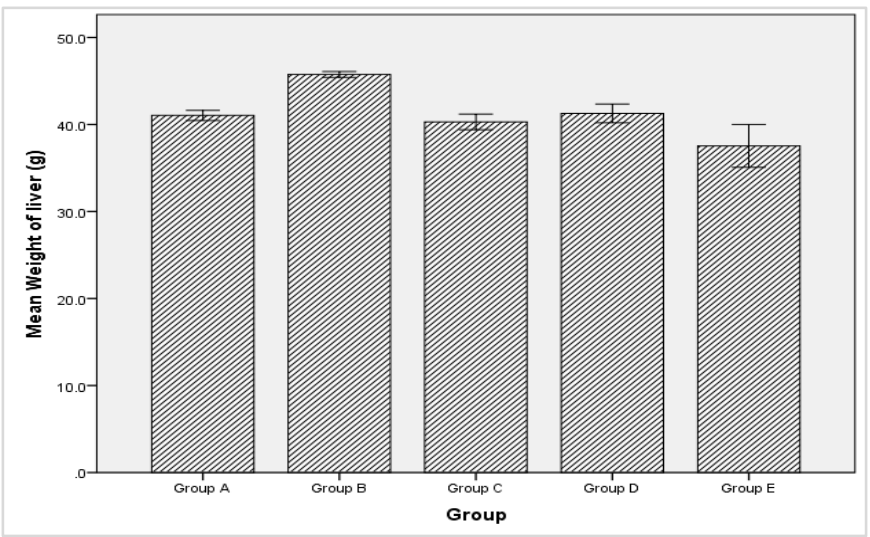

Fig. 2: Effect of R. sativus extract on liver weight (mean + SE) of atorvastatin treated rabbits $(n=10)$ 
Group A: Normal; Group B: Atorvastatin $20 \mathrm{mg} / \mathrm{kg}$ b.w./day; Group C: Atorvastatin $20 \mathrm{mg} / \mathrm{kg}$ b. w./day + $R$. sativus E. extract $100 \mathrm{mg} / \mathrm{kg}$ b.w./day; Group D: Atorvastatin $20 \mathrm{mg} / \mathrm{kg} \mathrm{b}$. w./day $+R$. sativus E. extract $200 \mathrm{mg} / \mathrm{kg}$ b.w./day; Group E: Atorvastatin $20 \mathrm{mg} / \mathrm{kg}$ b. $\mathrm{w} . /$ day $+R$. sativus E. extract $400 \mathrm{mg} / \mathrm{kg}$ b.w./day

Multiple comparison of liver weight by post hoc Tukey's test showed an insignificant difference except for group B which displayed significantly higher value when compared with group A (negative control). When compared with the positive control group B very highly significant less value were seen in group $E$ while group $C$ and $\mathrm{D}$ showed a highly significant and significant less value respectively.

Table 4: Comparison of means of liver weight among groups by post hoc Tukey's test

\begin{tabular}{|l|l|c|}
\hline \multicolumn{4}{|c|}{} & Significance \\
\hline \multirow{4}{*}{ Group A } & Group B & $0.014^{*}$ \\
\cline { 2 - 3 } & Group C & $0.688^{\mathrm{NS}}$ \\
\cline { 2 - 3 } & Group D & $0.901^{\mathrm{NS}}$ \\
\cline { 2 - 3 } & Group E & $0.064^{\mathrm{NS}}$ \\
\hline \multirow{3}{*}{ Group B } & Group C & $0.005^{* *}$ \\
\cline { 2 - 3 } & Group D & $0.019^{*}$ \\
\cline { 2 - 3 } & Group E & $0.000^{* * *}$ \\
\hline \multirow{3}{*}{ Group C } & Group D & $0.599^{\mathrm{NS}}$ \\
\cline { 2 - 3 } & Group E & $0.141^{\mathrm{NS}}$ \\
\hline Group D & Group E & $0.049^{*}$ \\
\hline
\end{tabular}

NS = Non-significant $(\mathrm{P} \geq 0.05) ;{ }^{*}=$ Significant $(\mathrm{P} \leq 0.05) ;{ }^{* *}=$ Highly significant $(\mathrm{P} \leq 0.01) ;{ }^{* *}=$ Very highly significant $(\mathrm{P} \leq 0.001)$

Liver/bodyweight ratio: Mean $\pm \mathrm{SD}$ values of liver weight/body weight ratio on $28^{\text {th }}$ day showed that all the groups exhibited higher values than the negative control group A. Group B showed the highest value while the group $\mathrm{E}$ had the lowest value. When compared by oneway analysis of variance, it was observed that all groups were significantly different.

Table 5: Effect of R. sativus extract on Liver/bodyweight ratio of atorvastatin treated rabbits. Data indicates mean $+\mathrm{SE}(\mathrm{n}=10)$

\begin{tabular}{|l|c|}
\hline Group & Mean \pm SE \\
\hline A: (control) & $0.0260 \pm 0.00031$ \\
\hline B: (At 20mg/kg/day) & $0.0363 \pm 0.0014$ \\
\hline $\begin{array}{l}\text { C: }(\text { At } 20 \mathrm{mg} / \mathrm{kg} / \text { day + R. S } \\
100 \mathrm{mg} / \mathrm{kg} / \text { day) }\end{array}$ & $0.0312 \pm 0.00084$ \\
\hline $\begin{array}{l}\text { D: }(\text { At } 20 \mathrm{mg} / \mathrm{kg} / \text { day + R. S } \\
200 \mathrm{mg} / \mathrm{kg} / \text { day) }\end{array}$ & $0.0307 \pm 0.00068$ \\
\hline $\begin{array}{l}\text { E: }(\text { At } 20 \mathrm{mg} / \mathrm{kg} / \text { day }+ \\
\text { R.S400mg/kg/day) }\end{array}$ & $0.0300 \pm 0.00132$ \\
\hline ANOVA (P value) & $0.000^{* * *}$ \\
\hline
\end{tabular}

NS = Non-significant $(\mathrm{P} \geq 0.05) ;{ }^{*}=$ Significant $(\mathrm{P} \leq 0.05) ;{ }^{* *}=$ Highly significant $(\mathrm{P} \leq 0.01) ;{ }^{* * *}=$ Very highly significant $(\mathrm{P} \leq 0.001)$

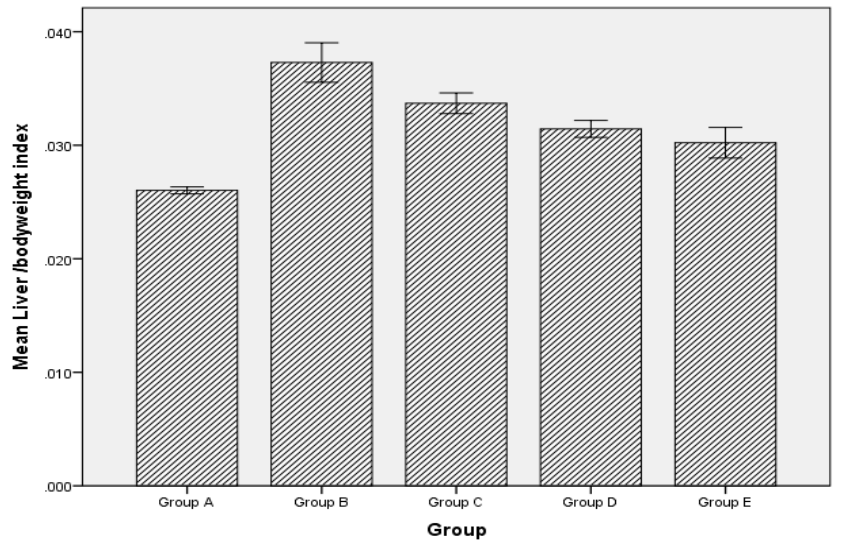

Fig. 3: Effect of R. sativus extract on liver/bodyweight ratio (mean $+\mathrm{SE})$ of atorvastatin treated rabbits $(n=10)$ Group A: Normal; Group B: Atorvastatin $20 \mathrm{mg} / \mathrm{kg}$ b.w./day; Group C: Atorvastatin $20 \mathrm{mg} / \mathrm{kg}$ b. w./day + $R$. sativus E. extract $100 \mathrm{mg} / \mathrm{kg}$ b.w./day; Group D: Atorvastatin $20 \mathrm{mg} / \mathrm{kg} \mathrm{b}$. w./day $+R$. sativus E. extract $200 \mathrm{mg} / \mathrm{kg}$ b.w./day; Group E: Atorvastatin 20mg/kg b. $\mathrm{w} . /$ day + R. sativus E. extract $400 \mathrm{mg} / \mathrm{kg}$ b.w./day;

Table below displays liver weight/body weight ratio on $28^{\text {th }}$ day by post hoc Tukey's test. The results showed a significantly higher value in all groups when compared with group A (negative control). When compared with the positive control group B all the groups showed a very highly significant lower value. Difference between all treated groups was insignificant.

Table 6: Comparison of means of liver/body weight ratio among groups by post hoc Tukey's test

\begin{tabular}{|l|l|c|}
\hline & & Significance \\
\hline \multirow{4}{*}{ Group A } & Group B & $0.0000^{* * *}$ \\
\cline { 2 - 3 } & Group C & $0.0007^{* * *}$ \\
\cline { 2 - 3 } & Group D & $0.0018^{* *}$ \\
\cline { 2 - 3 } & Group E & $0.0110^{*}$ \\
\hline \multirow{3}{*}{ Group B } & Group C & $0.0007^{* * *}$ \\
\cline { 2 - 3 } & Group D & $0.0003^{* * *}$ \\
\cline { 2 - 3 } & Group E & $0.0000^{* * *}$ \\
\hline \multirow{2}{*}{ Group C } & Group D & $0.7625^{\mathrm{NS}}$ \\
\cline { 2 - 3 } & Group E & $0.3348^{\mathrm{NS}}$ \\
\hline Group D & Group E & $0.5057^{\mathrm{NS}}$ \\
\hline
\end{tabular}

NS = Non-significant $(\mathrm{P} \geq 0.05) ;{ }^{*}=$ Significant $(\mathrm{P} \leq 0.05) ;{ }^{*}=$ Highly significant $(\mathrm{P} \leq 0.01) ;{ }^{* * *}=$ Very highly significant $(\mathrm{P} \leq 0.001)$

\section{DISCUSSION}

Raphanus sativus leaves are rich of flavonoids. They are used as antioxidants and thus conserve cellular integrity of the live cells. ${ }^{11}$ Being very common and economical, ethanolic extract of leaves of radish was used in three increasing doses to assess its hepato-protective properties against the hepatotoxicity due to atorvastatin in albino rabbits.

There was a decrease in body weight as observed on weekly basis over a period of 28 days as compared to the 
negative control group A which showed an increase in weight. This decrease was observed in all treated groups including the positive control group B. Although group E showed a further decrease in weight as compared to group B but it was insignificant. This was in accordance with a study by Salem and his colleagues in which simvastatin $(10 \mathrm{mk} / \mathrm{kg})$ was administered for ten weeks in rats which showed a 30\% reduction in body weight. ${ }^{12}$ The weight of liver decreases with the use of statins which may be attributed to decrease in cholesterol content with insignificant changes in triglycerols proteins and water content of liver ${ }^{7}$ In contrast to this study increase in weight with atorvastatin in group B was observed which may be due to hepatotoxic effects of atorvastatin. $12,13,14$ The treated groups C, D and E showed a decrease in weight on $28^{\text {th }}$ day and the effect was very highly significant in group $\mathrm{E}$ which is in accordance with a study by Syed and his colleagues in which $300 \mathrm{mg} / \mathrm{kg}$ dose of Raphanus sativus had a partial protective effect against hepatotoxicity induced by carbon tetrachloride. ${ }^{15}$

A comparison of liver to body weight ratio showed an increase in ratio especially group B when compared to group A which may be due to maximum increase in liver weight as stated above. The rest of the treated groups including $\mathrm{C}, \mathrm{D}$ and $\mathrm{E}$ showed a very highly significant decrease when compared with group $B$ with the maximum in group $\mathrm{E}$ but that was still significant when compared with the group A which was a reflection of changes in liver and body weight as discussed above.

\section{CONCLUSION}

The administration of $20 \mathrm{mg} / \mathrm{kg}$ toxic doses of atorvastatin lead to decrease in body weight in contrast to previous studies. Raphanus sativus did not show any significant additional decrease in weight when combined with atorvastatin.in contrast the weight of liver increased with Atorvastatin alone while addition of Raphanus sativus showed a significant decrease in weight.

\section{LIMITATIONS}

This is study is based on animal model so its results cannot be generalized without further trials.

\section{SUGGESTIONS / RECOMMENDATIONS}

The administration of atorvastatin lead to decrease in body weight in contrast to previous studies However, this can only be proven by further and comprehensive studies involving human subjects.

\section{CONFLICT OF INTEREST / DISCLOSURE}

No.

\section{ACKNOWLEDGEMENTS}

We acknowledge the staff of department of Clinical Medicine and Surgery, University of Agriculture, Faisalabad for animal handling.

\section{REFERENCES}

1. Brai B, Odetola A, Agomo P. Effects of Persea americana leaf extracts on body weight and liver lipids in rats fed hyperlipidaemic diet. African J Biotec. 2007;6(8)1007-11.

2. Popkin BM. An overview of the nutrition transition and its health implications: the Bellagio meeting. Public Health Nutr. 2002;5(1A):93-103.

3. Vivarelli F, Canistro D, Sapone A, De Nicola GR, Marquillas CB, Iori $R$, et al. Raphanus sativus cv. sango sprout juice decreases dietinduced obesity in Sprague Dawley rats and ameliorates related disorders. PloS one. 2016;11(3):e0150913.

4. Arçari DP, Bartchewsky W, Dos Santos TW, Oliveira KA, Funck A, Pedrazzoli J, et al. Antiobesity effects of yerba maté extract (ilex paraguariensis) in high-fat diet-induced obese mice. Obesity. 2009;17(12):2127-33.

5. Abolaji A, Adebayo H, Odesanmi O. Nutritional qualities of three medicinal plant parts (Xylopia aethiopica, Blighia sapida and Parinari polyandra) commonly used by pregnant women in the western part of Nigeria. Pak J Nutrition. 2007;6(6):665-8.

6. Adebayo A, Abolaji A, Opata T, Adegbenro I. Effects of ethanolic leaf extract of Chrysophyllum albidum G. on biochemical and haematological parameters of albino Wistar rats. Afri J Biotech. 2010;9(14):2145-50.

7. Aguirre L, Hijona E, Macarulla M, Gracia A, Larrechi I, Bujanda L, et al. Several statins increase body and liver fat accumulation in a model of metabolic syndrome. J Physiol Pharmacol. 2013;64(3):2818.

8. Salem N, Assaf N, Ahmed H. Pleiotropic effects of rimonabant and simvastatin on obesity associated multiple metabolic risk factors in rats. Eur Rev Med Pharmacol Sci. 2012;16(6):797-807.

9. Swerdlow DI, Preiss D, Kuchenbaecker KB, Holmes MV, Engmann JE, Shah T, et al. HMG-coenzyme A reductase inhibition, type 2 diabetes, and bodyweight: evidence from genetic analysis and randomised trials. The Lancet. 2015;385(9965):351-61.

10. Kim WK, Kim JH, Jeong DH, Chun YH, Kim SH, Cho KJ, et al. Radish (Raphanus sativus L. leaf) ethanol extract inhibits protein and mRNA expression of ErbB2 and ErbB3 in MDA-MB-231 human breast cancer cells. Nutr Res Pract. 2011;5(4):288-93.

11. Beevi SS, Narasu ML, Gowda BB. Polyphenolics profile, antioxidant and radical scavenging activity of leaves and stem of Raphanus sativus L. Plant Foods Hum Nutr. 2010;65(1):8-17.

12. Flora F. Treated Patients Biochemical Studies on the Hepatotoxicity of Atorvastatin. Int J Biochem \& Biophy. 2014;2(4):41-62.

13. Taleb MH, Almasri IM, Siam NI, Najim AA, Ahmed AI. The effect of atorvastatin on liver function among patients with coronary heart disease in Gaza Strip. Pharmacology \& Pharmacy. 2014;5(8):781-8.

14. Heeba GH, Abd-Elghany MI. Effect of combined administration of ginger (Zingiber officinale Roscoe) and atorvastatin on the liver of rats. Phytomedicine. 2010;17(14):1076-81.

15. Syed SN, Rizvi W, Kumar A, Khan AA, Moin S, Ahsan A. In Vitro Antioxidant and In Vivo Hepatoprotective Activity of Leave Extract of Raphanus sativus in Rats Using CCL 4 Model. Afr J Tradit Complement Altern Med. 2014;11(3):102-6. 